This is an electronic reprint of the original article. This reprint may differ from the original in pagination and typographic detail.

\author{
Author(s): Tynjälä, Päivi; Virtanen, Anne; Klemola, Ulla; Kostiainen, Emma; Rasku-Puttonen, \\ Helena
}

Title: Developing social competence and other generic skills in teacher education : applying the model of integrative pedagogy

Year: $\quad 2016$

Version:

Please cite the original version:

Tynjälä, P., Virtanen, A., Klemola, U., Kostiainen, E., \& Rasku-Puttonen, H. (2016).

Developing social competence and other generic skills in teacher education :

applying the model of integrative pedagogy. European Journal of Teacher Education, 39(3), 368-387. https://doi.org/10.1080/02619768.2016.1171314

All material supplied via JYX is protected by copyright and other intellectual property rights, and duplication or sale of all or part of any of the repository collections is not permitted, except that material may be duplicated by you for your research use or educational purposes in electronic or print form. You must obtain permission for any other use. Electronic or print copies may not be offered, whether for sale or otherwise to anyone who is not an authorised user. 


\section{Developing Social Competence and Other Generic Skills in Teacher Education: Applying the Model of Integrative Pedagogy}

Päivi Tynjälä, Anne Virtanen, Ulla Klemola, Emma Kostiainen and Helena Rasku-Puttonen

Corresponding author:

Päivi Tynjälä

Finnish Institute for Educational Research

PO Box 35, University of Jyväskylä,

40014 Jyväskylä, Finland

Tel: + 358504009464

Email: paivi.tynjala@jyu.fi

Anne Virtanen

Finnish Institute for Educational Research

PO Box 35, University of Jyväskylä, 40014 Jyväskylä, Finland

email: anne.virtanen@jyu.fi

Ulla Klemola

Department of Teacher Education

PO Box 35, University of Jyväskylä, 40014 Jyväskylä, Finland

email: ulla.klemola@jyu.fi

Emma Kostiainen

Department of Teacher Education

PO Box 35, University of Jyväskylä, 40014 Jyväskylä, Finland

email: emma.kostiainen@jyu.fi

Helena Rasku-Puttonen

Department of Teacher Education

PO Box 35, University of Jyväskylä, 40014 Jyväskylä, Finland

email: helena.rasku-puttonen@jyu.fi 


\title{
Developing Social Competence and Other Generic Skills in Teacher Education: Applying the Model of Integrative Pedagogy
}

\begin{abstract}
The purpose of the study was to examine how social competence and other generic skills can be developed in teacher education by using a pedagogical model called Integrative Pedagogy. This model is based on the idea of integrating the four basic components of expertise: Theoretical knowledge, practical knowledge, self-regulative knowledge, and socio-cultural knowledge. The subjects of the study were 95 student teachers. The data were collected with questionnaires. In addition to social skills, the student teachers reported learning of domain-specific skills, generic academic skills, skills for acting creatively in different situations, and development of independence. We conclude that the model of Integrative Pedagogy is feasible in teacher education.
\end{abstract}

Keywords: social competence, social interaction, social skills, teacher education, integrative pedagogy

\section{Introduction}

Social competence, or so-called people skills, are often mentioned as the most important skills in studies where employers or recently graduated employees are asked about generic attributes needed at work (e.g. Greene and Burleson 2003; Manninen and Hobrough 2000; Teichler 2007; Tynjälä et al. 2006). In the teaching profession, social competence is seen as fundamental for the following reasons. First, the core of the teacher's work is providing guidance in learning, which is essentially an interactive social process. Teachers need to observe the dynamics in the classroom, create social situations that support learning processes, and maintain relationships with students and their parents. Second, one task of the teachers is to teach social skills to their students, which makes learning and teaching these skills at the same time a first order and second order activity in teacher education (Murray and Male 2005). Third, in recent times the teaching profession has substantially transformed and extended from pure teaching activities towards diverse tasks of multi-professional collaboration where shared expertise and social skills are essential. Teachers cooperate with their colleagues and other professionals such as teaching assistants, 
counselors, and health care workers. Furthermore, upper secondary school teachers, especially vocational teachers, often collaborate closely with employers and workers at workplaces where their students are gaining work experience. Thus, it is no exaggeration to say that teachers' work is rooted in social interaction, and teachers need to possess sophisticated social competence.

As the concept of social competence has been used in many scientific fields, defining it has been challenging, and the definitions vary whether the research has been carried out with children or in the contexts of formal education or working life (e.g. Murakami et al. 2009; Siekkinen et al. 2013). A considerable amount of research has been conducted with children. In these studies social competence is usually defined as children's social skills such as cooperation skills, empathy, and control of impulsivity (e.g. Durlak, Weissberg, Dymnicki, Taylor, and Schellinger 2011; Hamre, Pianta, Mashburn, and Downer 2012). Research has shown that children's social skills tend to improve in different social settings and in relationships with peers (e.g. Siekkinen et al. 2013). The development of social competence is under-researched in adulthood and especially in the context of higher education, although the importance of social skills and other generic skills in work have been frequently addressed (Kember and Leung 2005; Murakami et al. 2009; Oberst, Gallifa, Farriols, and Vilaregut 2009). One of the few studies conducted in the context of teacher education indicated that as a result of formal training student teachers were able to transfer social skills and competences learnt into their teaching practice and managed to solve challenging interaction situations with pupils better than before (e.g. Klemola, HeikinaroJohansson, and O’Sullivan 2013). These findings encourage us to examine the development of social competence in teacher education in more detail. In the present study social competence is conceptualized as students capacity to perform skillfully and competently in various social settings. It is considered as a situated phenomenon, which includes those attitudes, skills, knowledge, characteristics and understanding that constitute the basis on which they act both as students and employees in their relations to others (e.g. Kostiainen 2003; Murakami et al. 2009.) Thus, social competence will be expressed in practical social skills such as listening to others, an ability to view a situation from others' perspective (perspective taking), communicating clearly, and collaboration skills. In working life social competence is 
needed with other generic skills such as independent working, critical thinking and problem solving skills (Teichler 2007).

The purpose of the present study was to examine how social competence and other generic skills can be developed in teacher education. We have conducted our study in Finland where the starting point of teacher education is the principle that education has to be grounded in research and theory on the topics to be taught and learnt. Accordingly, we have developed an approach to teaching social skills and other generic skills in the framework of a pedagogical model called Integrative Pedagogy (e.g. Heikkinen, Tynjälä, and Kiviniemi 2011; Tynjälä 2008; 2009), which is based on the socio-constructivist view of learning (e.g Duffy, Lowyck, and Jonassen 1993; Tynjälä 1999) and research on professional expertise (e.g. Bereiter 2002; Bereiter and Scardamalia 1993; Eraut 2004; Le Maistre and Paré 2006). Furthermore, the sociocultural approach to learning and theories of social interaction (e.g. Gordon 2003; Vygotsky 1962; 1978) have deeply informed the application and instructional design of our model.

\section{Integrative Pedagogy as a Starting Point}

The model of Integrative Pedagogy (Heikkinen, Tynjälä, and Kiviniemi 2011; Tynjälä 2008; 2009; Tynjälä et al. 2006; Tynjälä, Häkkinen, and Hämäläinen, 2014) is not a certain method of teaching but rather a principle of constructing learning environments. It is based on accounts of the nature of professional expertise (Bereiter 2002; Bereiter and Scardamalia 1993; Eraut 2004; Leinhardt, McCarthy Young, and Merriman 1995; Le Maistre and Paré 2006) consisting of four basic elements which are tightly integrated with each other, namely, theoretical, practical, self-regulative, and socio-cultural knowledge (see Figure 1). Theoretical knowledge is conceptual, explicit and formal in nature, whereas practical knowledge is experiential and often implicit, being embedded in skills. In order to develop professional competence, the interaction and integration of theoretical and practical knowledge is essential (e.g. Griffiths and Guile 2003; Guile and Griffiths 2001; Leinhardt, McCarthy Young, and Merriman, 1995). In other words, theories should be considered in the light of practice, and practical experiences in the light of theories. In Figure 1, the arrows between the 
boxes of theoretical and practical knowledge illustrate the interaction and integration of these two essential components of expertise.

\section{---INSERT FIGURE 1 ABOUT HERE---}

The third important constituent of expertise, self-regulative knowledge, involves metacognitive and reflective skills and knowledge (e.g. Bereiter 2002; Bereiter and Scardamalia 1993). The development of self-regulation is based on the learner's conscious reflection on his or her own activities. In the model of Integrative Pedagogy, reflection focusing on the learner's experiences is facilitated by theoretical concepts or models. In Figure 1, the arrows linking self-regulative knowledge with theoretical and practical knowledge illustrate reflection processes.

For making connections between different forms of knowledge, mediating tools are needed. Any activities that enable students to utilize theoretical concepts in practice or conceptualize and reflect on practical experiences are potential mediating tools. These include, for example, discussions with a tutor, mentor or a small group, or writing assignments such as analytical writing, self-reflective journals or reflective portfolios.

The mediating processes in integrating theoretical, practical and self-regulative knowledge are problem solving and integrative thinking. According to Bereiter and Scardamalia (1993, p. 66), formal knowledge is turned into skills when it is used to solve practical problems, and it is turned into an expert's informal knowledge when it is used to solve conceptual problems, that is, problems of understanding. Thus, the integration of theory, practice and self-regulation can be seen as a problem-solving process where students solve practical problems and related conceptual problems. While solving problems where they need to integrate different forms of knowledge the learners utilize a form of thinking called integrative thinking (e.g. Kallio 2011). This is higher order thinking requiring an individual to unite different, sometimes even conflicting, elements into an integrated whole.

The fourth basic component of expertise, socio-cultural knowledge, is embedded in social practices and tools and artifacts used in such practices (e.g., Bereiter 2002; Hakkarainen et al. 2004). It includes unspoken rules of social communities, the ways 
in which tools are used and different social practices. Therefore, participation in communities of practice (Wenger 1998) is the only way to get a feel of this form of knowledge. The ideal in the model of Integrative Pedagogy is that practical and sociocultural knowledge are provided through authentic work experience and when such opportunities are not available different kinds of simulation arrangements or exercises are organized (Tynjälä, Häkkinen, and Hämäläinen 2014).

In recent research literature the role of emotions in learning and professional development has emerged as an important element of learning (e.g. Arpiainen, Lackéus, Täks, and Tynjälä 2013; Pekrun, Frenzel, Goetz, and Perry 2007). The emotional level is especially highlighted in social competence development because the ability to recognize and deal with emotions is an important aspect of the competence (Reyes, Brackett, Rivers, White, and Salovey 2012; Rubin, Bukowski, and Parker 2006). Therefore, in the present study, we added a further component into the Integrative Pedagogy model, the emotional level. It is presented at the bottom of Figure 1 to emphasize that emotional aspects need to be taken into account in learning.

\section{Integrative Pedagogy as a Framework for Teaching Social Interaction Skills}

In the present study, we examine how the Integrative Pedagogy model works in two courses on social competence in teacher education at the University of Jyväskylä, Finland; namely, in a course on teachers' Interaction Skills in a Group and in Networks (ISGN), and in Social and Emotional Skills in Teaching (SEST) (Klemola, Heikinaro-Johansson, and O’Sullivan 2013; Rasku-Puttonen, Klemola, and Kostiainen 2013).

The development of the ISGN and the SEST courses is informed by the socio-cultural approach, which emphasizes socially and culturally mediated practices in learning (Wenger 1998). Therein, professional learning is seen as an ongoing process, occurring as student teachers participate in activities within different groups during their teacher education program. The participatory perspective (e.g. Sfard 1998) is one way to understand learning in different communities of practice. A community of practice can be seen as a group of participants who share knowledge in a joint 
enterprise and create resources that members develop in collaboration (Wenger 1998). Further, the course module SEST was guided by humanistic psychology (Gordon 2003) and philosophy of dialogue (e.g. Burbules 1993), with an emphasis on genuine interaction and one's possibility to change. Even though the two course modules have been developed separately, there are some theoretical and practical similarities between them (see Table 1). The common pedagogical main principle in both courses was that of Integrative Pedagogy, that is, integrating the main elements of professional expertise. The other instructional design principles were as follows, 1) the membership in and belonging to the group, 2) active participation, and 3) reflecting on experiences in light of theoretical knowledge.

\section{---INSERT TABLE 1 ABOUT HERE---}

Following Vygotsky (1962; 1978), we believe that social competence is developed through intensive participation in group processes. During the course modules, students worked in groups: in ISGN daily for one week, and in the SEST course once a week for an entire semester. According to the first instructional design principle, membership and belonging to a small group, students are provided with the possibility of taking on the perspectives of other group members in order to learn to view their own behavior from the perspective of others and to learn about their feelings related to their acceptance by the group. Multiple experiences with social challenges may trigger a set of cognitive and social practices internalized through the interaction with peer students. The aim of working in various group formations is to provide opportunities for comparatively observing the different dynamics emerging in small group interactions and those in whole-group interactions, both within and between the groups.

The second principle, active participation in activities, was realized through different kinds of exercises related to genuine everyday problems of pupils and student teachers. It is likely that most teachers of communication are in agreement with Michael Argyle and his associates (Trower, Bryant, and Argyle 1978, 71), that “practice is essential” in the acquisition of social skills. We suppose that the development of social competence is a lifewide process and the skills are learned in different social settings in a lifelong process. Personality researchers have found that personality traits such as 
extroversion have a genetic foundation but they also have indicated that personality traits and character traits such as cooperativeness follow different kinds of development trajectories, and that social environment is more strongly related to character than personality or temperament traits (Josefson et al., 2013a,b). In other words, people who score low in extroversion may still learn social skills.

As described in Figure 1, the relationship between theory and practice is crucial for learning, and the third instructional design principle was to support the reflection on practical experiences with the help of conceptual tools and theoretical knowledge. In both courses, experiences and interpretations of observations were reported and analyzed in the final report of the course. Writing and reflecting are activities that are assumed to develop student teachers' self-regulative knowledge and thus yield tools for their present studying and future profession.

Although the two courses follow the principles of Integrative Pedagogy there are many differences in the contents and pedagogical practices between them. The main differences between the ISGN and SEST courses can be summarized as follows. First, the theoretical contents of the course differed. While socio-constructivist and sociocultural perspective is common, the SEST course also relies on philosophy of dialogue and Thomas Gordon's (2003) model. Gordon taught communication skills that can used to improve good relationships at home, school and work. These skills include methods such as Active Listening, I-Messages, and No-Lose Conflict Resolution. Active listening is a way of reflecting back what the other person has said, to let them know that you are listening and to check your understanding of what he means. The idea of I-message is that instead of criticizing other people, one tells about her own feelings, while the purpose of no-lose conflict resolution is that both parties get a feeling of winning. Following this model, students had practical exercises whenever new theoretical ideas were presented. The exercises included practicing active listening, use of I-messages and win-win strategy in dealing with conflict situations. The ISGN course, in contrast, did not commit to the Gordon model but relied on a variety exercises that utilized students' own experiences. At the end part of the course the emphasis was in linking theory and practice with a writing assignment. Second, the student groups in the two courses differed from each other. ISGN students are primary school student teachers, while the SEST course is targeted to physical 
education student teachers. Third, SEST runs for the first year students, whereas ISGN students take the course on their second year. Fourth, small groups in the ISGN course are established on the basis of random selection, whereas in the SEST course students work in groups where they have already worked over a half year period in other subjects. Fifth, the team of teacher educators $(\mathrm{N}=5-6)$ plans and teaches in collaboration the ISGN course, whereas in the SEST course, only one teacher is responsible for the course. Last, but not least, the ISGN course is carried out in an intensive period of one week, whereas the SEST course is carried out once a week during one semester. Altogether, the two courses represent different contexts and different ways of applying the Integrative Pedagogy model. Therefore, we were interested whether students' perceptions of the pedagogy and learning outcomes would differ between the courses.

\section{Aim of the Study}

The purpose of our study was to investigate student teachers' experiences of learning social skills and other generic skills in the two courses applying the model of Integrative Pedagogy. We wanted to examine students' perceptions concerning actual learning activities and pedagogical features because there can be a gap in written curriculum and realized curriculum. Furthermore, we were interested whether the two different contexts and ways of applying the Integrative Pedagogy model would be perceived in different ways by students, and whether learning outcomes would differ. More specifically, we addressed the following research questions:

1. How do student teachers perceive pedagogical features of the courses in social skills?

2. Which generic skills and knowledge do student teachers learn during the courses?

3. Are there differences in perceptions of the student teachers between the two different courses a) in how they perceive the pedagogical features of the courses, and b) in which skills and knowledge they learn during those courses?

\section{Data}


The data were collected using an Internet questionnaire. The subjects were 129 student teachers from the courses Interaction Skills in a Group and in Networks (ISGN), and Social and Emotional Skills in Teaching (SEST), described earlier. In total, 95 student teachers (74\%) answered the questionnaires, 63 (72\%) from the ISGN course, and 32 (78\%) from the SEST course. The questionnaire consisted of three themes: 1) The students' self-assessed learning outcomes during the course 2) the perceived pedagogical features of the courses, and 3) the background information of respondents/students.

\section{Methods}

For answering our first research question about perceived pedagogical features of the courses, we used a set of questions comprising 22 statements, two different lists consisting of 12 different forms of teaching and studying (e.g., listening, reading, and lecturing), and 24 different pedagogical elements of the course (e.g., learning of theoretical knowledge, utilizing student teachers' earlier experiences, and comparing different theories). The questions sought to capture students' experiences of activities and the classroom atmosphere in the two courses. The questions were based on the features of constructivist learning environments (e.g., Duffy, Lowyck, and Jonassen 1993; Tynjälä 1999; Tynjälä et al. 2009) enriched by the elements of Integrative Pedagogy as described earlier, and the characteristics of learning environments identified as capable of nurturing generic capabilities in higher education (Kember, Leung, and Ma 2007). The students assessed every statement on a scale from 1 to 4 (1=strongly disagree, $2=$ disagree, $3=$ agree, and 4=strongly agree). The items on the lists related to the forms of teaching and the pedagogical elements of the course were assessed on a five-point scale (1=nothing, 2=some, 3=a fair amount, 4=a good deal, and $5=a$ great deal). The scales that measure the pedagogical features of the university courses were developed and validated over a long period of time in previous studies in vocational education and training (e.g. Virtanen, Tynjälä and Collin 2009; Virtanen and Tynjälä 2008; Virtanen, Tynjälä, and Eteläpelto, 2014; Virtanen, Tynjälä, and Valkonen, 2005). However, this part of the instrument has not been utilized before in university courses. Therefore, the contents of the survey, along 
with tables that describe its reliability and aggregated scales based on the factor analysis, are shown in the appendix (Tables 6-7).

To obtain answers to our second research question (What skills and knowledge do students learn during the courses?), we asked students to assess their learning outcomes in regard to 43 different skills. These skills were drawn from i.) recent studies on the development of generic skills among higher education and vocational students (e.g., Barnett 2004; Barrie 2007; Bath et al. 2004; Biggs 1999, Crebert et al. 2004a; Gilbert et al. 2004; Kember and Leung 2005; Kember, Leung, and Ma 2007; Robley, Whittle, and Murdoch-Eaton 2005; Rychen and Salganik 2003; Stenström 2006; Virtanen, Tynjälä, and Valkonen 2005), and ii.) skill descriptions within the European Qualification Framework (e.g., Gonzáles and Wagenaar 2003; 2005; Kallioinen 2010). Students were asked to assess these 43 different learning outcomes on a five-point scale ( 1 =nothing, $2=$ some, $3=a$ fair amount, $4=a$ good deal, and $5=a$ great deal). This part of the instrument was also developed over a long period of time to measure vocational students' learning at work (e.g. Virtanen, Tynjälä, and Valkonen, 2005; see also Virtanen, Tynjälä, and Collin, 2009). Based on the original instrument, a new version was developed to be more suitable for university contexts (Virtanen and Tynjälä 2010). Table 8 in the appendix describes the contents and reliability of this instrument. Of the five authors of this article the first two were independent researchers who were responsible for developing the research methods, analyses, and writing the results. These two researchers were not involved in planning and teaching of the courses. Other three authors were responsible for instructional design and teaching, and they wrote the sections describing pedagogical solutions of the courses.

The results are presented as mean values of the aggregated scales. The statistical significance of the differences between the means of the two courses was tested using the $u$-test (independent samples Mann-Whitney $u$-test). Effect sizes (Cohen's $d$ ) were calculated for independent sample $u$-tests in which the values of $0.2,0.5$ and 0.8 were considered to be small, moderate and large, respectively.

\section{Results}




\subsection{Pedagogical features of the courses}

\subsubsection{Forms of teaching and studying in the courses}

As can be seen in Table 2, the students perceived that the most commonly used forms of teaching were discussion (mean value 4.64, max. 5), working together with others (4.56), and listening (4.43). By contrast, there was less use of traditional forms of university teaching, such as reading, writing, and working alone.

\section{---INSERT TABLE 2 ABOUT HERE---}

There were statistically significant differences in some forms of teaching and studying between the two examined courses (see Table 2). Students in the SEST course assessed that discussion was used more, and they were working together with others more often than the students in the ISGN course felt about their experience. Similarly, students in the SEST course felt that they received more directions or guidance and feedback or evaluation from their teacher than the students in the ISGN course assessed they received. In contrast to the students in the SEST course, the ISGN students reported more use of the following forms of teaching: Observing, assessing one's own work, working alone, reading and lecturing. The effect sizes were also either large or moderate (0.98-0.52).

\subsubsection{The pedagogical elements of the courses}

Table 3 presents the mean values of the pedagogical elements of the courses assessed by the students. In both courses, students' own experiences were utilized in the teaching to a large extent (mean value 4.01, max. 5). Similarly, students also reported that they typically worked at the interface between theory and practice in the courses (3.81), and that the courses aimed at the development of a critical view in students

(3.55). Students were also assigned many kinds of feedback, assessment and summarizing tasks (3.37). Learning theoretical knowledge was regarded as a somewhat less important element of the courses, although the mean value was near the midpoint of the scale (2.96). There was only one statistically significant difference between the two courses. In comparison to students in the ISGN course, the SEST 
students more often felt that their teaching was operating at the interface between theory and practice. The effect size was also large, 0.70 .

\section{---INSERT TABLE 3 ABOUT HERE---}

\subsubsection{Activities and classroom atmosphere in the courses}

Table 4 shows that the students experienced the classroom atmosphere and procedures in the courses as having been extremely positive and collaborative. Students felt strongly that the threshold for discussion and asking questions was low (mean value 3.70, max. 4). Similarly, students reported that they frequently worked with other students (3.68). Students also indicated that the teaching was inspiring and competent, and that it was largely conducted at the interface between theory and practice (3.61). It is also noteworthy that the standard deviations between the three highest variables were congruent with others (.33-.36). Thus, the students agreed to a fair extent with the aforementioned matters.

\section{---INSERT TABLE 4 ABOUT HERE---}

There were some statistically significant differences between the two courses in regard to the assessments of the activities and classroom atmosphere (see Table 4). The students in the SEST course felt that they had more flexible arrangements and they felt that the teaching was inspiring and competent in more cases. The threshold for discussion and asking questions was seen to be lower in the SEST course than in the ISGN course. Students in the SEST course also reported that they had worked together with other students more frequently than was the case for students in the IGSN course. Similarly, the criteria for assessment seemed to be more clearly defined in the SEST course than in the ISGN course. Again, the effect sizes were either large or moderate (0.87-0.59).

\subsection{Students' self-reported learning outcomes in the courses}


Students reported that they had acquired wide-ranging knowledge and skills during their courses (see Table 5). In particular, the students felt that they had learned collaboration skills (mean value on the aggregate scale for collaboration skills $=3.83$, max. 5). They also reported having learnt a fairly wide range of domain-specific basic skills (3.77), generic academic skills (3.70), and skills for acting creatively in different situations (3.63). Students also reported an increase in self-confidence and responsibility (3.53). By contrast, the students reported less learning in independent working situations (2.71) and in skills for knowledge acquisition and analysis (2.11). Surprisingly, just one statistically significant difference appeared between these courses in regard to students' perceived learning outcomes (see Table 4). Students in the ISGN course reported an increase in self-confidence and responsibility more often (3.67) than did the students in the SEST course (3.25). The effect size was moderate, 0.64 .

---INSERT TABLE 5 ABOUT HERE---

\section{Discussion and Conclusions}

Although the importance of the development of generic skills has been strongly emphasized in recent debates on university education, there has been little systematic research on how these skills can be nurtured. In the present study, we examined student teachers' learning experiences in two courses focusing on the development of social competence, one of the most frequently mentioned generic attributes. Both courses were theoretically based on the model of Integrative Pedagogy but differed from each other in their contexts and the ways how the model was applied.

Our findings showed that the students in both courses perceived the pedagogical elements and activities of the course quite similarly, although some differences were found. In both classes, the students recognized the features and principles of the model of Integrative Pedagogy, slightly more so in the small groups of the SEST course, where students gave higher ratings in regard to acting at the interface between theory and practice; they also found the threshold for asking questions lower and the arrangements of the course more flexible. These differences may be explained by the fact that in this course, the integration of theory and practice was carried out at all 
times during the course; that is, the students were first introduced to theoretical ideas or concepts and immediately after this they had an opportunity to put theory into practice through exercises which were then followed by coming back to theory through reflection on the practice in light of the theoretical concepts. Thus, these students received practical tools in terms of exercising different situations. This mode of working was probably experienced as "integrating theory and practice" more often than was the case in the other course, where the application of theoretical concepts into practice and reflection on practical experiences took place in the form of being offered tools for thinking. Overall, rich interaction through discussions and collaborative exercises was typical of the SEST course.

Despite the differences between the two courses in their theoretical basis, in organization, and as regards to group working methods there were no differences between them in self-assessed learning outcomes, with the exception of selfconfidence and responsibility, for which the ISGN course students gave higher ratings. As expected, the students in both courses gave the highest ratings regarding the learning of collaboration skills. What was less expected was that they also gave high ratings to the learning of domain-specific basic skills, generic academic skills, skills for acting creatively in different situations, experiences of independence, and domainspecific theoretical knowledge. This may be due to the fact that both courses had a strong theoretical basis instead of being focused merely on practical experiences of social interaction. Indeed, characteristic of both courses was a deep integration of theoretical, practical and self-regulative knowledge - although carried out in different ways, as described before. In general, the learning outcomes generated by these two courses differed from those of more traditional university courses in which the skills of knowledge acquisition and analysis, as well as working independently, have been reported as being the most important outcomes in learning (e.g. Virtanen and Tynjälä 2010).

So far, other studies on mechanisms by which universities can develop generic attributes in students are rare. A study by Kember, Leung, and Ma (2007) is one of the few projects having pursued this aim. In their study, the learning environment which seemed conducive to the development of generic skills included the following features: high degree of collaborative learning, interaction, feedback and assistance, students’ 
active engagement in learning activities, and a variety of assessment methods focusing on understanding of key concepts. The role of collaborative learning has also been emphasized in studies by Crebert et al. (2004b), as well as by Ballantine and McCourt Larres (2007). Our study strongly confirms these findings, but it also raises a new pedagogical feature: the integration of theory and practice in learning and studying. Of course, this is not surprising as one of the main pedagogical principles directing the instructional design of both courses was applying the model of Integrative Pedagogy which emphasizes the importance of the integration of the key elements of professional expertise, that is, theoretical knowledge, practical knowledge, self-regulative knowledge, and socio-cultural knowledge. In further studies, it is important to elaborate how teaching can be organized so that it genuinely brings about interaction and integration between theory and practice. Our study shows that learners' reflecting on their experiences with conceptual tools is one key element in this kind of pedagogy. It is also important to note that reflection and interaction in the two special courses studied here took place with strong guidance from the teacher. This indicates that it is not enough for students to discuss their experiences, but that pedagogical structuring and guidance are also needed. Overall, it seems that realizing the model of Integrative Pedagogy indeed requires interactive forms of learning.

In the courses examined, the working methods typically simulate those of the working world. For example, discussions, sharing experiences, and collaboration are typical ways of communicating and learning at the workplace (e.g. Tynjälä, 2008). In our study it appeared that these methods and the integration of theory and practice are also key elements in supporting the development of social competence and other generic working life skills. Furthermore, it is typical in our model that the learning of generic skills is integrated with the development of domain-specific knowledge and expertise instead of these being organized as separate courses.

The findings of our study show that it is possible to apply the Integrative Pedagogy model to pedagogical practices in different ways and still to gain similar results. The theoretical contribution of the study is twofold. First, the results of the study give support to model of Integrative Pedagogy as a theoretical construction. The second contribution is the validation of scales measuring students' perceptions of pedagogical 
elements of their learning environment and of learning outcomes in the context of teacher education.

There are, however, certain limitations that need to be taken into account when interpreting the results. No pretesting of the skills was conducted and the results were based on students' self-evaluation instead of objective tests. We do not know either whether the learnt skills transfer to real life situations. Therefore, further studies are needed to confirm and elaborate the findings.

To conclude, our study indicates that integrative pedagogy offers a promising model for developing social competence and other generic skills in teacher education. Although the study was conducted in Finnish context we believe that the model is applicable and works in teacher education systems of other countries as well.

\section{References}

Arpiainen, R.-L., M. Lackéus, M. Täks, and P. Tynjälä. 2013. ”The Sources and dynamics of emotions in entrepreneurship education.” Trames: Journal of the Humanities and Social Sciences 17 (4): 383-399. doi: 10.3176/tr.2013.4.02

Ballantine, J., and P. McCourt Larres. 2007. Cooperative learning: a pedagogy to improve students' generic skills? Education + Training 49 (2): 126-137. doi: http://dx.doi.org/10.1108/00400910710739487.

Barnett, R. 2004. Learning for an unknown future. Higher Education Research \& Development 23 (3): 247-260. doi: http://dx.doi.org/10.1080/0729436042000235382.

Barrie, S. C. 2007. A conceptual framework for the teaching and learning of generic graduate attributes. Studies in Higher Education 32 (4): 439-458. doi: http://dx.doi.org/10.1080/03075070701476100.

Bath, D., C. Smith, S. Stein, and R. Swann. 2004. Beyond mapping and embedding graduate attributes: bringing together quality assurance and action learning to create a validated and living curriculum. Higher Education Research \& Development 23 (3): 313-328. doi: http://dx.doi.org/10.1080/0729436042000235427.

Bereiter, C. 2002. Education and Mind in the Knowledge Age. Mahwah, NJ: Erlbaum. 
Bereiter, C., and M. Scardamalia. 2003. Learning to work creatively with knowledge. In Powerful learning environments: Unravelling basic components and dimensions edited by E. de Corte, L. Verschaffel, N. Entwistle, and J. van Merriënboer, 55-68. Amsterdam: Pergamon.

Biggs, J. 1999. Teaching for quality learning at university. What the student does. The Society for Research into Higher Education. Buckingham: Open University Press.

Burbules, N. 1993. Dialogue in teaching. Theory and practice. New York, NY: Teachers College Press.

Crebert, G., M. Bates, B. Bell, C.-J. Patrick, and V. Cragnolini. 2004a. Developing generic skills at university, during work placement and in employment: graduates’ perceptions. Higher Education Research \& Development 23 (2): 147165. doi: http://dx.doi.org/10.1080/0729436042000206636.

Crebert, G., M. Bates, B. Bell, C.-J. Patrick, and V. Cragnolini. 2004b. Ivory tower to concrete jungle revisited. Journal of Education and Work 17 (1): 47-70. doi: http://dx.doi.org/10.1080/1363908042000174192.

Duffy, T. M., J. Lowyck, and D. H. Jonassen, eds. 1993. Designing Environments for Constructive Learning. NATO ASI Series. Series F: Computer and Systems Sciences, (105). Berlin: Springer.

Durlak, J. A., R. P. Weissberg, A. B. Dymnick, R. D. Taylor, and K. B. Schellinger 2011.The impact of enhancing students' social and emotional learning: A metaanalysis of school-based universal interventions. Child Development 82 (1): 405-432. doi: http://dx.doi.org/10.1111/j.1467-8624.2010.01564.x.

Eraut, M. 2004. Informal learning in the workplace. Studies in Continuing Education 26 (2): 247-173. doi: http://dx.doi.org/10.1080/158037042000225245.

Gilbert, R., J. Balatti, P. Turner, and H. Whitehouse. 2004. The generic skills debate in research higher degrees. Higher Education Research \& Development 23 (3): 375-388. doi: http://dx.doi.org/10.1080/0729436042000235454.

Gonzáles, J., and R. Wagenaar, eds. 2003. Tuning Educational Structures in Europe. Final Report. Phase One. Bilbao: Universidad de Deusto.

Gonzáles, J., and R. Wagenaar, eds. 2005. Tuning Educational Structures in Europe. Universities' Contribution to the Bologna Process. Final Report. Phase Two. Bilbao: Universidad de Deusto. 
Gordon, T. 2003. Teachers' effectiveness training. The program proven to help teachers bring out the best in students of all ages. New York, NY: Three Rivers Press.

Greene, J. O., and B. R. Burleson. 2003. Handbook of Communication and Social Interaction Skills. Mahwah, NJ: Lawrence Erlbaum.

Griffiths, T., and D. Guile. 2003. A connective model of learning: the implications for work process knowledge. European Educational Research Journal 2 (1): 56-73. http://ejournals.ebsco.com/direct.asp?ArticleID=2PKBYTD1GFU59L4HHER8

Guile, D., and T. Griffiths. 2001. Learning through work experience. Journal of Education and Work 14 (1): 113-131. doi: http://dx.doi.org/10.1080/13639080020028738.

Hakkarainen, K., T. Palonen, S. Paavola, and E. Lehtinen. 2004. Communities of networked expertise: Professional and educational perspectives. Amsterdam: Elsevier.

Hamre, B. K., R. C. Pianta, A. J. Mashburn, and J. T. Downer 2012. Early Education and Development 23 (6): 809-832. doi: http://dx.doi.org/10.1080/10409289.2011.607360

Heikkinen, H. L. T., P. Tynjälä, and U. Kiviniemi. 2011. Integrative pedagogy in practicum: Meeting the second order paradox of teacher education. In $A$ practicum turn in teacher education edited by M. Mattson, T.V. Eilertsen, and D. Rorrison, 91-112. Rotterdam: Sense Publishers.

Josefsson, K., M Jokela, M. Hintsanen, C.R. Cloninger, L. Pulkki-Råback, P. Merjonen, N. Hutri-Kähönen, N. and L. Keltikangas-Järvinen, L. 2013. Parental care-giving and home environment predicting offspring's temperament and character traits after 18 years. Psychiatry Research 209, 643-651. http://dx.doi.org/10.1016/j.psychres.2013.01.007.

Josefsson, K., M. Jokela, C.R. Cloninger, M. Hintsanen, J. Salo, T. Hintsa, L. PulkkiRåback, and L Keltikangas-Järvinen. 2013. Development and Psychopathology 25, 713-727. doi: 10.1017/S09545794113000126

Kallioinen, O. 2010. Defining and comparing generic competences in higher education. European Educational Research Journal 9 (1): 56-68. http://ejournals.ebsco.com/direct.asp?ArticleID=40EF88705D68EBB70499

Kember, D., and D. Y. P. Leung. 2005. Influence of the teaching and learning environment on the development of generic capabilities needed for a 
knowledge-based society. Learning Environments Research 8 (3): 245-266. doi: http://dx.doi.org/10.1007/s10984-005-1566-5.

Kember, D., D. Y. P. Leung, and R. S. F. Ma. 2007. Characterizing learning environments capable of nurturing generic capabilities in higher education. Research in Higher Education 48 (5): 609-632. doi: http://dx.doi.org/10.1007/s11162-006-9037-0.

Klemola, U., P. Heikinaro-Johansson, and M. O’Sullivan. 2013. Physical education student teachers' perceptions of applying knowledge and skills about emotional understanding in PETE in a one-year teaching practicum. Physical Education and Sport Pedagogy 18 (1): 1-14. doi: http://dx.doi.org/10.1080/17408989.2011.630999

Kostiainen, E. 2003. Viestintä ammattiosaamisen ulottuvuutena [Communication as a dimension of vocational competence]. Jyväskylä Studies in Humanities 1. University of Jyväskylä.

Leinhardt, G., K. McCarthy Young, and J. Merriman. 1995. Integrating professional knowledge: The theory of practice and the practice of theory. Learning and Instruction 5: 401-408. doi: http://dx.doi.org/10.1016/0959-4752(95)00025-9

Le Maistre, C., and A. Paré. 2006. A typology of the knowledge demonstrated by beginning professionals. In Higher Education and working life. Collaborations, confrontations and challenges edited by P. Tynjälä, J. Välimaa, and G. BoultonLewis, 103-113. Amsterdam: Elsevier.

Manninen, J., and J. Hobrough. 2000. Skills gaps and overflows? A European perspective of graduate skills and employment in SMEs. Industry \& Higher Education 14 (1): 51-57. doi: http://dx.doi.org/10.5367/000000000101294869.

Mead, G. 1934/1962. Mind, Self, and Society. From the standpoint of a social behaviorist. Edited by C. W. Morris. Chicago: The University of Chicago Press.

Murakami, K., L. Murray, D. Sims, D., and K. Chedzey 2009. Learning on Work Placement: The Narrative Development of Social Competence. Journal of Adult Development 16:13-24. doi: http://dx.doi.org/10.1007/s10804-008-9044-9

Murray, J., and T. Male. 2005. Becoming a teacher educator: evidence from the field. Teaching and Teacher Education 21 (2): 125-142. doi: http://dx.doi.org/10.1016/j.tate.2004.12.006.

Oberst, U., J. Gallifa, N. Farriols, and A. Vilaregut 2009. Training Emotional and 
Social Competences in Higher Education: The Seminar Methodology. Higher

Education in Europe 34 (3): 523-533. doi: http://dx.doi.org/ 10.1080/03797720903392243.

Pekrun, R., A.C. Frenzel, T. Goetz, and R.P. Perry. 2007. The control-value theory of achievement emotions: an integrative approach to emotions in education. In Emotions in education edited by P. Schutz and R. Pekrun, 13-36. Burlington, MA: Academic Press.

Rasku-Puttonen, H., U. Klemola, and E. Kostiainen. 2011. Supporting student teachers' social interaction competence in teacher education. In Educating teachers in the PISA paradise. Perspectives on teacher education at a Finnish university edited by M. Kontoniemi and O.-P. Salo, 89-102. University of Jyväskylä. Jyväskylä Teaching Training School. Publications 12.

Reyes M.R., M.A. Brackett, S.E. Rivers, M. White, and P. Salovey. 2012. Classroom emotional climate, student engagement, and academic achievement. Journal of Educational Psychology 104 (3), 700-712.

Robley, W., S. Whittle, and D. Murdoch-Eaton. 2005. Mapping generic skills curricula: a recommended methodology. Journal of Further and Higher Education 29 (3), 221-231. doi: http://dx.doi.org/10.1080/03098770500166801.

Rubin, K.H., W.M. Bukowski, and J.G. Parker. 2006. Peer interactions, relationships, and groups. In Handbook of child psychology: vol 3. Social, emotional and personality development, $6^{\text {th }}$ ed. Edited by W. Damon and R.M. Lerner (Series eds), and N. Eisenberg (Vol. Ed.), 571-645. Hoboken, NJ: Wiley.

Rychen, D.S., and L. H. Salganik, eds. 2003. Key competencies for successful life and well-functioning society. Cambridge, MA: Hogrefe \& Huber.

Sfard, A. 1998. On two metaphors for learning and the dangers of choosing just one. Educational Researcher 27 (2): 4-13. http://www.jstor.org/stable/1176193.

Siekkinen, M., E. Pakarinen, M-K. Lerkkanen, A-M. Poikkeus, J. Salminen, J., E. Poskiparta, and J-E. Nurmi. 2013. Social competence among 6-year-old children and classroom instructional support and teacher stress. Early Education and Development 24(6), 877-897. doi: 10.1080/10409289.2013.745183

To link to this article: http://dx.doi.org/10.1080/10409289.2013.745183

Stenström, M.-L. 2006. Polytechnic graduates’ working-life skills and expertise. In Higher education and working life. Collaborations, confrontations and 
challenges edited by P. Tynjälä, J. Välimaa, and G. Boulton-Lewis, 89-102. Amsterdam: Elsevier.

Teichler, U. 2007. Does higher education matter? Lessons from a comparative graduate study. European Journal of Education 42 (1): 11-34. doi: http://dx.doi.org/10.1111/j.1465-3435.2007.00287.x.

Trower, P., B. Bryant, and M. Argyle. 1978. Social skills and mental health. London: Methuen.

Tynjälä, P. 1999. Towards Expert Knowledge? A Comparison between a Constructivist and a Traditional Learning Environment in University. International Journal of Educational Research 31 (5): 357-442.

Tynjälä, P. 2008. Perspectives into learning at the workplace. Educational Research Review 3 (2): 130-154. doi: http://dx.doi.org/10.1016/j.edurev.2007.12.001.

Tynjälä, P. 2009. Connectivity and transformations in work-related learning Theoretical foundations. In Towards integration of work and learning. Strategies for connectivity and transformation edited by M.-L. Stenström and P. Tynjälä, 11-37. Dordrecth: Springer.

Tynjälä, P., P. Häkkinen, and R. Hämäläinen. 2014. TEL@work: Toward integration of theory and practice. British Journal of Educational Technology 45(6), 9901000. doi:10.1111/bjet.12164.

Tynjälä, P., M. Pirhonen, T. Vartiainen, and L. Helle. 2009. Educating IT project managers through project-based learning: A working-life perspective. The Communications of the Association for Information Systems 24: 270-288. http://aisel.aisnet.org/cais/vol24/iss1/16.

Tynjälä, P., V. Slotte, J. Nieminen, K. Lonka, and E. Olkinuora. 2006. From university to working life: Graduates' workplace skills in practice. In Higher education and working life: Collaborations, confrontations and challenges edited by P. Tynjälä, J. Välimaa, and G. Boulton-Lewis, 73-88. Amsterdam: Elsevier.

Virtanen, A. and P. Tynjälä. 2008. Students' experiences of workplace learning in Finnish VET. European Journal of Vocational Training 44(2). 199-213.

Virtanen, A., and P. Tynjälä 2010. Students' experiences of learning generic skills in university studies. Paper presented at the European Conference on Educational Research (ECER), Helsinki, Finland, August 25-27. 
Virtanen, A., P. Tynjälä, and K. Collin. 2009. Characteristics of workplace learning among Finnish vocational students. Vocations and Learning 2 (3), 153-175. DOI 10.1007/s12186-009-9022-9

Virtanen, A., P. Tynjälä, and A. Eteläpelto. 2014. Factors promoting vocational students' learning at work: Study on student experiences. Journal of Education and Work 27 (1), 43-70. DOI: 10.1080/13639080.2012.718748

Virtanen, A., P. Tynjälä, and S. Valkonen. 2005. Työssäoppiminen opiskelijoiden arvioimana Helsingin kaupungin ammatillisissa oppilaitoksissa. [Workplace learning system assessed by students in vocational schools of Helsinki] Helsingin kaupungin opetusviraston julkaisusarja, A1.

Vygotsky, L. S. 1962. Thought and language. Cambridge: MIT Press.

Vygotsky, L. S. 1978. Mind in society: The development of higher psychological processes. Edited and translated by M. Cole, V. John-Steiner, S. Sribner, and E. Souberman. Cambridge, MA: Harvard University Press.

Wenger, E. 1998. Communities of practice. Learning, meaning and identity. Cambridge: Cambridge University Press. 
Table 1. Description of the two interaction skill courses

\begin{tabular}{|c|c|c|}
\hline Course module descriptions & $\begin{array}{l}\text { Interaction Skills in a Group } \\
\text { and in Networks (ISGN) }\end{array}$ & $\begin{array}{l}\text { Social and Emotional Skills } \\
\text { in Teaching (SEST) }\end{array}$ \\
\hline Credits & 4 ects & 2 ects \\
\hline Theoretical framework & $\begin{array}{l}\text { Socio-cultural theories } \\
\text { a Socio-constructivism } \\
\text { a Dynamic group processes }\end{array}$ & $\begin{array}{l}\text { Socio-cultural theories } \\
\text { a Socio-constructivism } \\
\text { a Humanistic psychology } \\
\text { (Thomas Gordon) } \\
\text { a Philosophy of dialogue }\end{array}$ \\
\hline Aims & $\begin{array}{l}\text { Student } \\
\propto \text { is able to analyze his/her } \\
\text { social competence } \\
\square \text { is able to recognize and } \\
\text { evaluate group processes and } \\
\text { his/her individualistic behavior } \\
\text { as a member of a group } \\
\text { a recognizes the importance } \\
\text { of multi-professional } \\
\text { collaboration } \\
\text { a has the capability to improve } \\
\text { the welfare of the learning } \\
\text { community }\end{array}$ & $\begin{array}{l}\text { Student } \\
\propto \text { is able to analyze his/her } \\
\text { social competence } \\
\propto \text { is able to develop his/her } \\
\text { social and emotional skills }\end{array}$ \\
\hline Students & $\begin{array}{l}\text { Primary school teacher } \\
\text { students in their } 2^{\text {nd }} \text { academic } \\
\text { year }\end{array}$ & $\begin{array}{l}\text { Physical education teacher } \\
\text { students in their } 1^{\text {st }} \text { academic } \\
\text { year }\end{array}$ \\
\hline Teachers & $\begin{array}{l}\text { Team of teacher educators } \\
\text { from different disciplines }\end{array}$ & $\begin{array}{l}\text { One teacher educator of } \\
\text { physical education pedagogy }\end{array}$ \\
\hline Pedagogical principles & $\begin{array}{l}\text { One week } \\
\text { a } 30 \text { hours contact teaching, } \\
\text { ca. } 80 \text { hours independent } \\
\text { work } \\
\text {-Integrative Pedagogy } \\
\text {-Belonging to the group } \\
\text {-Active participation } \\
\text {-Reflecting on experiences } \\
\text {-Concentrating on the } \\
\text { phenomenon of social } \\
\text { interaction } \\
\text {-Learning processes support } \\
\text { the } \\
\text { learning contents } \\
\text {-Special emphasis on } \\
\text { beginning } \\
\text { and ending the course module } \\
\text {-Holistic view of the learner } \\
\text {-Increasing awareness of one's } \\
\text { own emotions, behavior and } \\
\text { reactions } \\
\text {-Multiprofessional cooperation }\end{array}$ & $\begin{array}{l}\text { One semester } \\
\text { a } 20 \text { hours contact teaching, } \\
\text { ca. } 30 \text { hours independent } \\
\text { work } \\
\text {-Integrative Pedagogy } \\
\text {-Belonging to the group } \\
\text {-Active participation } \\
\text {-Reflecting on experiences } \\
\text {-Learning-by-doing } \\
\text {-Special emphasis on } \\
\text { beginning } \\
\text { and ending the course module } \\
\text {-Transfer of learned skills and } \\
\text { attitudes to practices } \\
\text { and reflection } \\
\text {-Learning processes support } \\
\text { the } \\
\text { learning contents } \\
\text {-Increasing self-knowledge } \\
\text { and collaboration within the } \\
\text { group }\end{array}$ \\
\hline $\begin{array}{l}\text { Teaching and studying } \\
\text { methods }\end{array}$ & $\begin{array}{l}\text {-Whole group sessions } \\
\text {-Small group activities } \\
\text {-Open discussions } \\
\text {-Simulations } \\
\text {-Role play } \\
\text {-Teacher as a member of the }\end{array}$ & $\begin{array}{l}\text {-Small group activities } \\
\text {-Open discussions } \\
\text {-Role play } \\
\text {-Teacher as a member of the } \\
\text { group } \\
\text {-Personal feedback of the }\end{array}$ \\
\hline
\end{tabular}




\begin{tabular}{|c|c|c|}
\hline & $\begin{array}{l}\text { group } \\
\text {-Peer reflections } \\
\text {-Perceiving, naming and } \\
\text { regulating emotions } \\
\text {-Commitment to and trust in } \\
\text { the } \\
\text { group } \\
\text {-Reflective reading and writing } \\
\text {-Versatile methods for } \\
\text { receiving and providing } \\
\text { feedback and evaluations } \\
\text { about the course and the } \\
\text { activities in the group } \\
\end{array}$ & $\begin{array}{l}\text { teacher } \\
\text {-Commitment to and trust in } \\
\text { the } \\
\text { group } \\
\text {-Reflective reading and } \\
\text { writing }\end{array}$ \\
\hline Assessment & $\begin{array}{l}\text { Rating scale } 0-5 \\
\text {-Includes an essay and } \\
\text { students' self-assessment of } \\
\text { the intensive study week }\end{array}$ & $\begin{array}{l}\text { Fail-pass } \\
\text {-Includes one reflective report } \\
\text { and an essay } \\
\text {-Self-assessment of learning }\end{array}$ \\
\hline
\end{tabular}


Table 2. Mean values of variables describing the forms of teaching in the courses (min. 1, max. 5)

\begin{tabular}{|c|c|c|c|c|c|}
\hline Forms of teaching & $\begin{array}{l}\text { Both } \\
\text { courses } \\
\mathrm{n}=91 \\
\text { Mean } \\
\text { value } \\
\text { (SD) }\end{array}$ & $\begin{array}{l}\text { ISGN* } \\
\mathrm{n}=57 \\
\text { Mean } \\
\text { value } \\
\text { (SD) }\end{array}$ & $\begin{array}{l}\text { SEST }^{* *} \\
\\
\mathrm{n}=31 \\
\text { Mean } \\
\text { value } \\
\text { (SD) }\end{array}$ & $\begin{array}{l}\text { Significance } \\
\text { of differences } \\
\text { between } \\
\text { the courses } \\
\text { (Mann-Whitney } \\
u \text {-test) }\end{array}$ & $\begin{array}{l}\text { Effect size } \\
\text { (Cohen’s } d \text { ) }\end{array}$ \\
\hline -Discussion & $\begin{array}{l}4.64 \\
(.55)\end{array}$ & $\begin{array}{l}4.55 \\
(.59)\end{array}$ & $\begin{array}{l}4.81 \\
(.40)\end{array}$ & .033 & 0.55 \\
\hline $\begin{array}{l}\text {-Working together with } \\
\text { others }\end{array}$ & $\begin{array}{l}4.56 \\
(.64)\end{array}$ & $\begin{array}{l}4.46 \\
(.70)\end{array}$ & $\begin{array}{l}4.75 \\
(.44)\end{array}$ & .050 & 0.52 \\
\hline -Listening & $\begin{array}{l}4.43 \\
(.56)\end{array}$ & $\begin{array}{l}4.45 \\
(.57)\end{array}$ & $\begin{array}{l}4.41 \\
(.56)\end{array}$ & .699 & 0.07 \\
\hline $\begin{array}{l}\text {-Directions or guidance } \\
\text { from teacher }\end{array}$ & $\begin{array}{l}3.62 \\
(.72)\end{array}$ & $\begin{array}{l}3.47 \\
(.72)\end{array}$ & $\begin{array}{l}3.91 \\
(.64)\end{array}$ & .005 & 0.71 \\
\hline -Assessing one’s own work & $\begin{array}{l}3.49 \\
(.86)\end{array}$ & $\begin{array}{l}3.68 \\
(.81)\end{array}$ & $\begin{array}{l}3.13 \\
(.83)\end{array}$ & .003 & 0.66 \\
\hline -Observing & $\begin{array}{l}3.49 \\
(.92)\end{array}$ & $\begin{array}{l}3.78 \\
(.87)\end{array}$ & $\begin{array}{l}2.94 \\
(.76)\end{array}$ & .001 & 0.98 \\
\hline -Lecturing & $\begin{array}{l}3.29 \\
(.74)\end{array}$ & $\begin{array}{l}3.42 \\
(.68)\end{array}$ & $\begin{array}{l}3.03 \\
(.78)\end{array}$ & .009 & 0.53 \\
\hline $\begin{array}{l}\text {-Feedback / evaluation } \\
\text { given by teacher }\end{array}$ & $\begin{array}{l}3.21 \\
(.90)\end{array}$ & $\begin{array}{l}3.08 \\
(.94)\end{array}$ & $\begin{array}{l}3.44 \\
(.76)\end{array}$ & .050 & 0.39 \\
\hline $\begin{array}{l}\text {-Assessment of other } \\
\text { students' work }\end{array}$ & $\begin{array}{l}3.16 \\
(.83)\end{array}$ & $\begin{array}{l}3.15 \\
(.88)\end{array}$ & $\begin{array}{l}3.19 \\
(.74)\end{array}$ & .780 & 0.04 \\
\hline -Writing & $\begin{array}{l}2.57 \\
(.56)\end{array}$ & $\begin{array}{l}2.60 \\
(.56)\end{array}$ & $\begin{array}{l}2.50 \\
(.57)\end{array}$ & .549 & 0.17 \\
\hline -Reading & $\begin{array}{l}2.37 \\
(.57)\end{array}$ & $\begin{array}{l}2.47 \\
(.62)\end{array}$ & $\begin{array}{l}2.19 \\
(.40)\end{array}$ & .024 & 0.56 \\
\hline -Working alone & $\begin{array}{l}2.29 \\
(.60)\end{array}$ & $\begin{array}{l}2.40 \\
(.64)\end{array}$ & $\begin{array}{l}2.09 \\
(.47)\end{array}$ & .021 & 0.58 \\
\hline
\end{tabular}

* ISGN = Interaction Skills in a Group and in Networks

** SEST $=$ Social and Emotional Skills in Teaching 
Table 3. Mean values of aggregate scales and single variables describing the pedagogical elements of the courses (min. 1, max. 5)

\begin{tabular}{|c|c|c|c|c|c|}
\hline Pedagogical elements & $\begin{array}{l}\text { Both } \\
\text { courses } \\
\mathrm{n}=91 \\
\text { Mean } \\
\text { value } \\
\text { (SD) }\end{array}$ & $\begin{array}{l}\text { ISGN* } \\
\mathrm{n}=59 \\
\text { Mean } \\
\text { value } \\
\text { (SD) }\end{array}$ & $\begin{array}{l}\text { SEST** } \\
\\
\mathrm{n}=32 \\
\text { Mean } \\
\text { value } \\
\text { (SD) }\end{array}$ & $\begin{array}{l}\text { Significance } \\
\text { of differences } \\
\text { between } \\
\text { the courses } \\
\text { (Mann-Whitney } \\
u \text {-test) }\end{array}$ & $\begin{array}{l}\text { Effect size } \\
\text { (Cohen’s } d \text { ) }\end{array}$ \\
\hline -Sharing experiences & $\begin{array}{l}4.01 \\
(.66)\end{array}$ & $\begin{array}{l}4.07 \\
(.67)\end{array}$ & $\begin{array}{l}3.91 \\
(.65)\end{array}$ & .239 & 0.22 \\
\hline $\begin{array}{l}\text {-Acting at the interface } \\
\text { between theory and } \\
\text { practice }\end{array}$ & $\begin{array}{l}3.81 \\
(.66)\end{array}$ & $\begin{array}{l}3.65 \\
(.65)\end{array}$ & $\begin{array}{l}4.10 \\
(.57)\end{array}$ & .002 & 0.70 \\
\hline $\begin{array}{l}\text {-Development of a critical } \\
\text { mind }\end{array}$ & $\begin{array}{l}3.55 \\
(.83)\end{array}$ & $\begin{array}{l}3.49 \\
(.94)\end{array}$ & $\begin{array}{l}3.65 \\
(.57)\end{array}$ & .292 & 0.21 \\
\hline $\begin{array}{l}\text {-Feedback, assessment, and } \\
\text { summarizing of tasks }\end{array}$ & $\begin{array}{l}3.37 \\
(.65)\end{array}$ & $\begin{array}{l}3.40 \\
(.69)\end{array}$ & $\begin{array}{l}3.31 \\
(.57)\end{array}$ & .707 & 0.13 \\
\hline $\begin{array}{l}\text {-Learning theoretical } \\
\text { knowledge }\end{array}$ & $\begin{array}{l}2.96 \\
(.63)\end{array}$ & $\begin{array}{l}2.92 \\
(.65)\end{array}$ & $\begin{array}{l}3.03 \\
(.59)\end{array}$ & .328 & 0.18 \\
\hline
\end{tabular}

* ISGN = Interaction Skills in a Group and in Networks

** SEST $=$ Social and Emotional Skills in Teaching 
Table 4. Mean values of aggregate scales and single variables describing the activities and classroom atmosphere in the courses (min. 1, max. 4)

\begin{tabular}{|c|c|c|c|c|c|}
\hline $\begin{array}{l}\text { Activities and } \\
\text { classroom atmosphere } \\
\text { in the courses }\end{array}$ & $\begin{array}{l}\text { Both } \\
\text { courses } \\
\mathrm{n}=91 \\
\text { Mean } \\
\text { value } \\
\text { (SD) }\end{array}$ & $\begin{array}{l}\text { ISGN* } \\
\mathrm{n}=60 \\
\text { Mean } \\
\text { value } \\
\text { (SD) }\end{array}$ & $\begin{array}{l}\text { SEST** } \\
\qquad \mathrm{n}=31 \\
\text { Mean } \\
\text { value } \\
\text { (SD) }\end{array}$ & $\begin{array}{l}\text { Significance } \\
\text { of differences } \\
\text { between } \\
\text { the courses } \\
\text { (Mann-Whitney } \\
u \text {-test) }\end{array}$ & $\begin{array}{l}\text { Effect size } \\
\text { (Cohen's } d \text { ) }\end{array}$ \\
\hline $\begin{array}{l}\text {-Low threshold for } \\
\text { discussion and asking } \\
\text { questions }\end{array}$ & $\begin{array}{l}3.70 \\
(.36)\end{array}$ & $\begin{array}{l}3.62 \\
(.36)\end{array}$ & $\begin{array}{l}3.85 \\
(.30)\end{array}$ & .001 & 0.64 \\
\hline $\begin{array}{l}\text {-Working together with } \\
\text { other students }\end{array}$ & $\begin{array}{l}3.68 \\
(.33)\end{array}$ & $\begin{array}{l}3.62 \\
(.34)\end{array}$ & $\begin{array}{l}3.81 \\
(.29)\end{array}$ & .002 & 0.56 \\
\hline $\begin{array}{l}\text {-Inspiring and competent } \\
\text { teaching at the interface of } \\
\text { theory and practice }\end{array}$ & $\begin{array}{l}3.61 \\
(.36)\end{array}$ & $\begin{array}{l}3.53 \\
(.37)\end{array}$ & $\begin{array}{l}3.77 \\
(.30)\end{array}$ & .001 & 0.81 \\
\hline -Learner’s responsibility & $\begin{array}{l}3.58 \\
(.54)\end{array}$ & $\begin{array}{l}3.61 \\
(.52)\end{array}$ & $\begin{array}{l}3.50 \\
(.57)\end{array}$ & .331 & 0.21 \\
\hline $\begin{array}{l}\text {-Well-defined criteria for } \\
\text { assessment }\end{array}$ & $\begin{array}{l}3.48 \\
(.72)\end{array}$ & $\begin{array}{l}3.35 \\
(.78)\end{array}$ & $\begin{array}{l}3.72 \\
(.72)\end{array}$ & .025 & 0.59 \\
\hline -Deep and holistic learning & $\begin{array}{l}3.30 \\
(.46)\end{array}$ & $\begin{array}{l}3.29 \\
(.49)\end{array}$ & $\begin{array}{l}3.31 \\
(.42)\end{array}$ & .983 & 0.04 \\
\hline -Student's voice is heard & $\begin{array}{l}2.92 \\
(.71)\end{array}$ & $\begin{array}{l}3.00 \\
(.64)\end{array}$ & $\begin{array}{l}2.78 \\
(.83)\end{array}$ & .177 & 0.36 \\
\hline $\begin{array}{l}\text {-Flexible course } \\
\text { arrangements }\end{array}$ & $\begin{array}{l}2.66 \\
(.91)\end{array}$ & $\begin{array}{l}2.40 \\
(.83)\end{array}$ & $\begin{array}{l}3.16 \\
(.85)\end{array}$ & .001 & 0.87 \\
\hline
\end{tabular}

* ISGN = Interaction Skills in a Group and in Networks

** SEST $=$ Social and Emotional Skills in Teaching 
Table 5. Mean values of aggregate scales and single variables describing students' self-reported learning outcomes during the courses (min. 1, max. 5)

\begin{tabular}{|c|c|c|c|c|c|}
\hline Learning outcomes & $\begin{array}{l}\text { Both } \\
\text { courses } \\
\mathrm{n}=91 \\
\text { Mean } \\
\text { value } \\
\text { (SD) }\end{array}$ & $\begin{array}{l}\text { ISGN* } \\
\mathrm{n}=57 \\
\text { Mean } \\
\text { value } \\
\text { (SD) }\end{array}$ & $\begin{array}{l}\text { SEST** } \\
\mathrm{n}=31 \\
\text { Mean } \\
\text { value } \\
\text { (SD) }\end{array}$ & $\begin{array}{l}\text { Significance } \\
\text { of differences } \\
\text { between } \\
\text { the courses } \\
\text { (Mann-Whitney } \\
u \text {-test) }\end{array}$ & $\begin{array}{l}\text { Effect size } \\
\text { (Cohen’s } d \text { ) }\end{array}$ \\
\hline -Collaboration skills & $\begin{array}{l}3.83 \\
(.61)\end{array}$ & $\begin{array}{l}3.81 \\
(.65)\end{array}$ & $\begin{array}{l}3.88 \\
(.54)\end{array}$ & .809 & 0.12 \\
\hline $\begin{array}{l}\text {-Domain-specific basic } \\
\text { skills }\end{array}$ & $\begin{array}{l}3.77 \\
(.61)\end{array}$ & $\begin{array}{l}3.76 \\
(.65)\end{array}$ & $\begin{array}{l}3.80 \\
(.51)\end{array}$ & .854 & 0.06 \\
\hline -Generic academic skills & $\begin{array}{l}3.70 \\
(.63)\end{array}$ & $\begin{array}{l}3.70 \\
(.71)\end{array}$ & $\begin{array}{l}3.71 \\
(.43)\end{array}$ & .661 & 0.03 \\
\hline $\begin{array}{l}\text {-Skills for acting creatively } \\
\text { in different situations }\end{array}$ & $\begin{array}{l}3.63 \\
(.63)\end{array}$ & $\begin{array}{l}3.57 \\
(.68)\end{array}$ & $\begin{array}{l}3.75 \\
(.54)\end{array}$ & .182 & 0.28 \\
\hline $\begin{array}{l}\text {-Self-confidence and } \\
\text { responsibility }\end{array}$ & $\begin{array}{l}3.53 \\
(.67)\end{array}$ & $\begin{array}{l}3.67 \\
(.71)\end{array}$ & $\begin{array}{l}3.25 \\
(.49)\end{array}$ & .001 & 0.64 \\
\hline $\begin{array}{l}\text {-Domain-specific theoretical } \\
\text { knowledge }\end{array}$ & $\begin{array}{l}3.16 \\
(.73)\end{array}$ & $\begin{array}{l}3.07 \\
(.79)\end{array}$ & $\begin{array}{l}3.34 \\
(.60)\end{array}$ & .060 & 0.37 \\
\hline -Working independently & $\begin{array}{l}2.71 \\
(.79)\end{array}$ & $\begin{array}{l}2.75 \\
(.88)\end{array}$ & $\begin{array}{l}2.63 \\
(.61)\end{array}$ & .447 & 0.15 \\
\hline $\begin{array}{l}\text {-Multidisciplinary } \\
\text { collaboration and } \\
\text { internationalization skills }\end{array}$ & $\begin{array}{l}2.51 \\
(.80)\end{array}$ & $\begin{array}{l}2.56 \\
(.86)\end{array}$ & $\begin{array}{l}2.41 \\
(.68)\end{array}$ & .339 & 0.18 \\
\hline $\begin{array}{l}\text {-Skills for knowledge } \\
\text { acquisition and analysis }\end{array}$ & $\begin{array}{l}2.11 \\
(.55)\end{array}$ & $\begin{array}{l}2.18 \\
(.59)\end{array}$ & $\begin{array}{l}1.98 \\
(.45)\end{array}$ & .151 & 0.36 \\
\hline -Career planning skills & $\begin{array}{l}2.08 \\
(.87)\end{array}$ & $\begin{array}{l}2.18 \\
(.93)\end{array}$ & $\begin{array}{l}1.91 \\
(.71)\end{array}$ & .218 & 0.30 \\
\hline
\end{tabular}

* ISGN = Interaction Skills in a Group and in Networks

** SEST $=$ Social and Emotional Skills in Teaching 


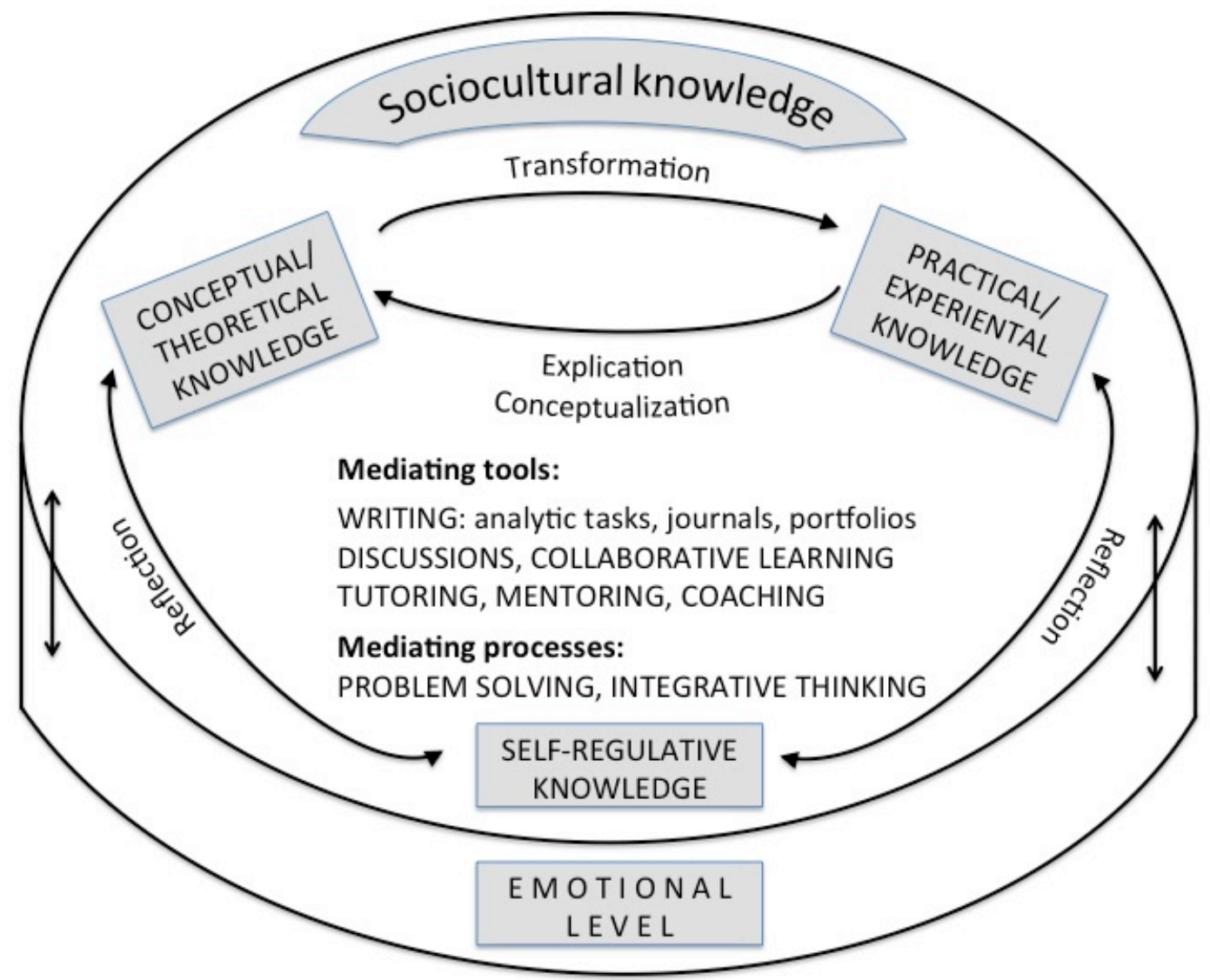

Figure 1. The model of Integrative Pedagogy (adapted from Heikkinen, Tynjälä, and Kiviniemi 2011; Tynjälä 2008; Tynjälä, Häkkinen \& Hämäläinen, 2014) 


\section{Appendix}

Table 6. Alphas, items, and correlations of aggregate scales describing the pedagogical elements of the courses

\begin{tabular}{|c|c|c|c|}
\hline Aggregate scale & $\begin{array}{l}\text { Cronbach's } \\
\text { alpha }\end{array}$ & Items & $\begin{array}{l}\text { Correlations } \\
\text { of items } \\
\text { with the } \\
\text { aggregate scale }\end{array}$ \\
\hline Sharing experiences & .89 & $\begin{array}{l}\text { - Sharing personal experiences } \\
\text { - Learning from other students' experiences } \\
\text { - Utilizing other students' experiences } \\
\text { - Utilizing other students' previous knowledge }\end{array}$ & $\begin{array}{l}.838 \\
.820 \\
.810 \\
.550\end{array}$ \\
\hline $\begin{array}{l}\text { Acting at the interface } \\
\text { between theory and } \\
\text { practice }\end{array}$ & .88 & $\begin{array}{l}\text { - Acquiring practical knowledge } \\
\text { - Integrating theory and practice } \\
\text { - Describing and demonstrating } \\
\text { practical examples by teacher } \\
\text { - Connections between teaching and } \\
\text { working life } \\
\text { - Looking for examples by oneself } \\
\text { - Applying theory to practice } \\
\text { - Analyzing familiar phenomena } \\
\text { with the help of theoretical knowledge }\end{array}$ & $\begin{array}{l}.778 \\
.771 \\
.678 \\
658 \\
.649 \\
.629 \\
\\
\end{array}$ \\
\hline $\begin{array}{l}\text { Feedback, assessment, } \\
\text { and summarizing of tasks }\end{array}$ & .87 & $\begin{array}{l}\text { - Receiving feedback } \\
\text { - Learning to give feedback } \\
\text { - Summarizing key issues by students } \\
\text { - Summarizing key issues by teacher } \\
\text { - Developing ability to evaluate } \\
\text { - Analyzing one’s own learning experiences } \\
\text { with the help of theoretical knowledge }\end{array}$ & $\begin{array}{l}.827 \\
.781 \\
.670 \\
.628 \\
.584 \\
.573\end{array}$ \\
\hline $\begin{array}{l}\text { Development of } \\
\text { a critical mind }\end{array}$ & .86 & $\begin{array}{l}\text { - Analyzing issues from different perspectives } \\
\text { - Critical evaluation of theories by teacher } \\
\text { - Critical evaluation of theories by students } \\
\text { - Developing ones' critical view } \\
\text { - Seeking different explanations to the } \\
\text { same issue } \\
\text { - Comparing different theories }\end{array}$ & $\begin{array}{l}.708 \\
.676 \\
.666 \\
.656 \\
.610 \\
.581\end{array}$ \\
\hline
\end{tabular}


Table 7. Alphas, items, and correlations of aggregate scales describing the activities and classroom atmosphere in the courses

\begin{tabular}{|c|c|c|c|}
\hline Aggregate scale & $\begin{array}{l}\text { Cronbach's } \\
\text { alpha }\end{array}$ & $\begin{array}{l}\text { Correla } \\
\text { of item } \\
\text { with th } \\
\text { aggreg. }\end{array}$ & tions \\
\hline $\begin{array}{l}\text { Low threshold for } \\
\text { discussion and asking } \\
\text { questions }\end{array}$ & .84 & $\begin{array}{l}\text { - It was easy to share my own opinions } \\
\text { and thoughts. } \\
\text { - It was easy to get my own voice heard. } \\
\text { - It was easy to speak my own mind } \\
\text { during the course. } \\
\text { - Teaching was interactive. } \\
\text { - There was a low threshold to ask things that } \\
\text { remained unclear. }\end{array}$ & $\begin{array}{l}.667 \\
.658 \\
.647 \\
.643 \\
.640\end{array}$ \\
\hline $\begin{array}{l}\text { Working together } \\
\text { with other students }\end{array}$ & .82 & $\begin{array}{l}\text { - There was a good 'we-ness' in the course. } \\
\text { - Collaboration with other students was } \\
\text { easy. } \\
\text { - An ability to work with others was } \\
\text { important during this course. } \\
\text { - It was possible to get feedback of my own } \\
\text { actions. }\end{array}$ & $\begin{array}{l}.734 \\
.701 \\
.687 \\
.562\end{array}$ \\
\hline Deep and holistic learning & .79 & $\begin{array}{l}\text { - My learning was deep. } \\
\text { - The course encouraged me to link } \\
\text { new knowledge to wider contexts. } \\
\text { - There were clear goals in the course. } \\
\text { - The course helped me to see the processes of } \\
\text { thinking and decision-making in this discipline. }\end{array}$ & $\begin{array}{l}.691 \\
.619 \\
.476 \\
.471\end{array}$ \\
\hline $\begin{array}{l}\text { Inspiring and competent } \\
\text { teaching at the interface of } \\
\text { theory and practice }\end{array}$ & .74 & $\begin{array}{l}\text { - Theory and practice were adequately } \\
\text { integrated with each other in this course. } \\
\text { - The teacher shared their enthusiasm of the subject } \\
\text { with us (students). } \\
\text { - The teaching was competent. }\end{array}$ & $\begin{array}{l}.576 \\
.568 \\
.547\end{array}$ \\
\hline
\end{tabular}


Table 8. Alphas, items, and correlations of aggregate scales describing students' self-reported learning outcomes during the courses

\begin{tabular}{|c|c|c|c|}
\hline Aggregate scale & $\begin{array}{r}\text { Cronbach's } \\
\text { alpha }\end{array}$ & Items & $\begin{array}{l}\text { Correlations } \\
\text { of items } \\
\text { with the } \\
\text { aggregate scale }\end{array}$ \\
\hline Collaboration skills & .91 & $\begin{array}{l}\text { - Collaboration skills } \\
\text { - Seeing things from the perspectives of others } \\
\text { - Ability to evaluate the actions of others } \\
\text { - Interaction skills } \\
\text { - Development of one's ethical view } \\
\text { - Leadership skills }\end{array}$ & $\begin{array}{l}.801 \\
.799 \\
.765 \\
.764 \\
.747 \\
.661\end{array}$ \\
\hline $\begin{array}{l}\text { Skills for knowledge } \\
\text { acquisition and analysis }\end{array}$ & .87 & $\begin{array}{l}\text { - Computer skills } \\
\text { - Scientific thinking } \\
\text { - Research skills } \\
\text { - Written communication skills } \\
\text { - Skills for knowledge acquisition } \\
\text { - Skills for knowledge analysis } \\
\text { - Foreign language skills }\end{array}$ & $\begin{array}{l}.693 \\
.674 \\
.667 \\
.655 \\
.619 \\
.616 \\
.615\end{array}$ \\
\hline Generic academic skills & .86 & $\begin{array}{l}\text { - Problem solving skills } \\
\text { - Decision making skills } \\
\text { - Oral communications skills } \\
\text { - Self-assessment skills } \\
\text { - Planning and organization skills } \\
\text { - Ability to handle conflicting information } \\
\text { - Critical thinking skills }\end{array}$ & $\begin{array}{l}.787 \\
.763 \\
.693 \\
.616 \\
.590 \\
.542 \\
.434\end{array}$ \\
\hline $\begin{array}{l}\text { Self-confidence and } \\
\text { responsibility }\end{array}$ & .85 & $\begin{array}{l}\text { - Increasing one’s self-confidence } \\
\text { - Increasing one's initiative } \\
\text { - Increasing one's responsibility } \\
\text { - Increasing awareness on one’s own } \\
\text { know-how } \\
\text { - Project-work skills }\end{array}$ & $\begin{array}{l}.742 \\
.741 \\
.690 \\
.617 \\
.568\end{array}$ \\
\hline $\begin{array}{l}\text { Skills for acting creatively } \\
\text { in different situations }\end{array}$ & .82 & $\begin{array}{l}\text { - Ability to operate in new situations } \\
\text { - Ability to solve occupational } \\
\text { problems } \\
\text { - Ability to apply learnt skills and knowledge } \\
\text { in diffierent situations } \\
\text { - Resourcefulness, innovativeness or } \\
\text { creativity } \\
\text { - Continuing learning skills }\end{array}$ & $\begin{array}{l}.644 \\
.639 \\
.627 \\
.622 \\
.504\end{array}$ \\
\hline $\begin{array}{l}\text { Multidisciplinary } \\
\text { collaboration and } \\
\text { internationalization skills }\end{array}$ & .78 & $\begin{array}{l}\text { - Ability to operate with people from other fie } \\
\text { - Internationalization skills } \\
\text { - Multicultural skills }\end{array}$ & $\begin{array}{l}.649 \\
.637 \\
.593\end{array}$ \\
\hline $\begin{array}{l}\text { Domain-specific basic } \\
\text { skills }\end{array}$ & .77 & $\begin{array}{l}\text { - Increasing one’s knowledge of working life } \\
\text { - Basic skills of one’s occupation/field } \\
\text { - Developing an overall picture of one’s field } \\
\text { - General knowledge }\end{array}$ & $\begin{array}{l}.658 \\
.619 \\
.564 \\
.477\end{array}$ \\
\hline
\end{tabular}


Career-planning and entrepreneurial sills
.76

- Planning one's own career .630

- Entrepreneurial skills 